\title{
Influence of Genistein on Hepatic Lipid Metabolism in an In Vitro Model of Hepatic Steatosis
}

\author{
Lena Seidemann ${ }^{1,2} \mathbb{D}$, Anne Krüger ${ }^{3}$, Victoria Kegel-Hübner ${ }^{1}$, Daniel Seehofer ${ }^{1,3}$ and Georg Damm ${ }^{1,2,3, * \mathbb{D}}$ \\ 1 Department of Hepatobiliary Surgery and Visceral Transplantation, University Hospital, Leipzig University, \\ 04103 Leipzig, Germany; lena.seidemann@medizin.uni-leipzig.de (L.S.); victoria.kegel@yahoo.de (V.K.-H.); \\ daniel.seehofer@medizin.uni-leipzig.de (D.S.) \\ 2 Saxonian Incubator for Clinical Translation (SIKT), Leipzig University, 04103 Leipzig, Germany \\ 3 Department of General, Visceral and Transplantation Surgery, Charité University Medicine Berlin, \\ 13353 Berlin, Germany; anne.krueger@med.uni-greifswald.de \\ * Correspondence: georg.damm@medizin.uni-leipzig.de; Tel.: +49-341-9739656
}

Citation: Seidemann, L.; Krüger, A.; Kegel-Hübner, V.; Seehofer, D.;

Damm, G. Influence of Genistein on Hepatic Lipid Metabolism in an In Vitro Model of Hepatic Steatosis. Molecules 2021, 26, 1156. https:// doi.org/10.3390/molecules26041156

Academic Editor: Julian Weghuber

Received: 6 January 2021

Accepted: 16 February 2021

Published: 22 February 2021

Publisher's Note: MDPI stays neutral with regard to jurisdictional claims in published maps and institutional affiliations.

Copyright: (c) 2021 by the authors. Licensee MDPI, Basel, Switzerland. This article is an open access article distributed under the terms and conditions of the Creative Commons Attribution (CC BY) license (https:// creativecommons.org/licenses/by/ $4.0 /)$.

\begin{abstract}
Nonalcoholic fatty liver disease (NAFLD) is among the leading causes of end-stage liver disease. The impaired hepatic lipid metabolism in NAFLD is exhibited by dysregulated PPAR $\alpha$ and SREBP-1c signaling pathways, which are central transcription factors associated with lipid degradation and de novo lipogenesis. Despite the growing prevalence of this disease, current pharmacological treatment options are unsatisfactory. Genistein, a soy isoflavone, has beneficial effects on lipid metabolism and may be a candidate for NAFLD treatment. In an in vitro model of hepatic steatosis, primary human hepatocytes (PHHs) were incubated with free fatty acids (FFAs) and different doses of genistein. Lipid accumulation and the cytotoxic effects of FFAs and genistein treatment were evaluated by colorimetric and enzymatic assays. Changes in lipid homeostasis were examined by RT-qPCR and Western blot analyses. PPAR $\alpha$ protein expression was induced in steatotic PHHs, accompanied by an increase in CPT1L and ACSL1 mRNA. Genistein treatment increased PPAR $\alpha$ protein expression only in control PHHs, while CPTL1 and ACSL1 were unchanged and PPAR $\alpha$ mRNA was reduced. In steatotic PHHs, genistein reversed the increase in activated SREBP-1c protein. The model realistically reflected the molecular changes in hepatic steatosis. Genistein suppressed the activation of SREBP-1c in steatotic hepatocytes, but the genistein-mediated effects on PPAR $\alpha$ were abolished by high hepatic lipid levels.
\end{abstract}

Keywords: liver; primary human hepatocytes; steatosis; NAFLD; NASH; Genistein; PPAR $\alpha$; SREBP-1c

\section{Introduction}

Nonalcoholic fatty liver disease (NAFLD) is the most common cause of chronic liver disease worldwide, with a global prevalence of approximately $25 \%$ [1,2]. It is considered the hepatic manifestation of metabolic syndrome and comprises a wide spectrum of liver impairments, starting with hepatic steatosis, which can progress to more severe liver damage, e.g., steatohepatitis (NASH), fibrosis and cirrhosis [3]. Predictably, NAFLD is becoming one of the leading indications for liver transplantation in the United States and in Europe [4,5]. Moreover, the growing incidence of hepatic steatosis in donor organs aggravates the problem of organ shortage [6].

Hepatic steatosis, the first stage of NAFLD, is marked by intracellular accumulation of triglycerides due to increased uptake of free fatty acids (FFAs), augmented de novo lipogenesis and impaired fatty acid $\beta$-oxidation [7-9]. The underlying molecular mechanisms are not fully understood but are currently being extensively studied, with the goal of a possible drug target to enable pharmacological NAFLD treatment [10].

One key player in hepatic lipid metabolism is peroxisome proliferator-activated receptor alpha (PPAR $\alpha)$, a ligand-activated transcription factor that is highly expressed in the liver [11]. The binding of FFAs to PPAR $\alpha$ induces the transcription of several genes 
involved in mitochondrial FFA $\beta$-oxidation and FFA transport [12]. Intracellular processing of long-chain fatty acids has to be preceded by their activation to acyl-coenzyme A (acylCoA) via long-chain acyl-CoA synthetases (ACSL). ACSL1 is the predominant isoform in the liver and a target gene of PPAR $\alpha[13,14]$. After esterification by ACSL1, long-chain acylCoA can enter $\beta$-oxidation via active transport into the mitochondria. The rate-limiting step of this process is transport through the outer mitochondrial membrane by carnitine palmitoyltransferase 1L (CPT1L), another transcription product of PPAR $\alpha[14,15]$.

Sterol regulatory element-binding protein 1c (SREBP-1c) is a central transcriptional regulator of hepatic de novo lipogenesis [9]. Insulin induces the expression of an inactive SREBP-1c precursor bound to the endoplasmic reticulum (ER) and likewise promotes its activation by proteolytic cleavage [16]. SREBP-1c then induces the expression of enzymes synthesizing fatty acids, i.e., acetyl-CoA carboxylase (ACC) and fatty acid synthase (FASN), which together catalyze the synthesis of palmitic acid $[9,17]$.

Liver biopsies of NAFLD patients have shown increased expression of SREBP-1c and its target genes and decreased expression of PPAR $\alpha$ and CPT1L $[18,19]$. To compensate for the reduced mitochondrial $\beta$-oxidation, the upregulated gene expression of enzymes engaged in peroxisomal $\beta$-oxidation and microsomal $\omega$-oxidation was observed [19]. These pathways are less effective in breaking down fatty acids and lead to an accumulation of reactive oxygen species (ROS) as byproducts [20]. Oxidative stress likely plays a crucial role in inflammation and hepatocyte damage observed in NAFLD [21]. This proinflammatory situation may be even more enhanced by the inhibition of $\operatorname{PPAR} \alpha$, a known negative regulator of inflammation and acute phase response, thus paving the way for disease progression from hepatic steatosis to steatohepatitis [22,23].

To date, no drug for NAFLD therapy is available. NAFLD management consists of a multimodal approach, similar to the treatment for metabolic syndrome, mainly focusing on lifestyle changes, i.e., improving diet and physical activity. Pharmacological treatments aim for the amelioration of associated metabolic disorders, such as hypertriglyceridemia [24].

Soy isoflavones, so-called phytoestrogens, have recently gained interest because of their beneficial effects on menopausal complaints and have also been proposed to positively affect metabolic syndrome and associated diseases due to their antioxidative and hypolipidemic properties [25-27]. An 8-week oral supplementation with genistein, the most abundant isoflavone of soybean, reduced oxidative and inflammatory indices alongside improvements in fat metabolism in NAFLD patients [28]. Genistein treatment further attenuated the development of steatosis in rodent in vitro and in vivo models [29-31]. This improvement was accompanied by a reversal of the FFA-induced downregulation of PPAR $\alpha$ and its downstream targets, such as CPT1L [29,31].

Primary human hepatocytes (PHHs) are still considered the gold standard for the creation of in vitro liver models [10]. A recent publication has underlined the protective effects of genistein against NAFLD also in PHHs [32]. However, in the above-mentioned studies, genistein was administered prior to or throughout a steatotic treatment, thus underlining its role in NAFLD prevention [29-32]. In our study, we sought to investigate the effects of genistein on hepatic lipid metabolism after manifestation of steatosis. Therefore, $\mathrm{PHHs}$ were treated with FFAs to induce in vitro steatosis and treated with different concentrations of genistein. The in vitro steatosis and the effect of genistein on steatotic and control PHHs were investigated by evaluating lipid storage, cytotoxic effects and changes in lipid homeostasis. Our results show that our in vitro steatosis model was characterized by high lipid accumulation accompanied by mild lipotoxic effects and a lipid-related shift in signaling towards lipid metabolism. Treatment of steatotic and control PHHs with genistein revealed that a high lipid load eliminated the beneficial effects of genistein on lipid metabolism, which were clearly visible in control PHHs. 


\section{Results}

\subsection{Incubation of PHHs with Free Fatty Acids Leads to Intracellular Lipid Accumulation}

After PHH isolation and initial adherence overnight, steatosis was induced by incubation with $1 \mathrm{mM}$ FFAs consisting of a mixture of oleate and palmitate in a 2:1 ratio for $24 \mathrm{~h}$. The intracellular lipid accumulation was determined with the Oil Red O assay normalized to the protein content measured with the sulforhodamine B (SRB) assay. FFA-treated PHHs showed a significant accumulation of neutral lipids (Figure 1A) visible in a larger number and size of intracellular lipid droplets (Figure 1B).

A

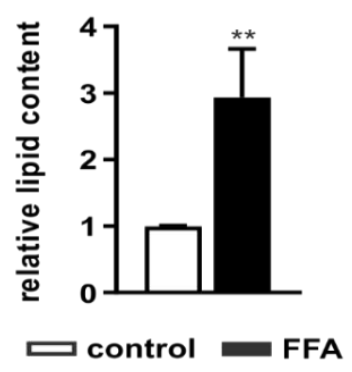

B

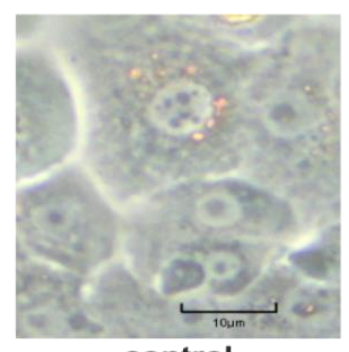

control

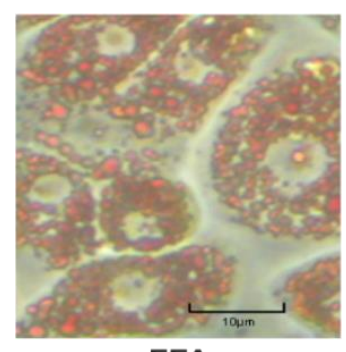

FFA

Figure 1. Amount of neutral lipids in primary human hepatocytes (PHHs) after treatment with free fatty acids (FFAs). PHHs were treated with $1 \mathrm{mM}$ FFAs for $24 \mathrm{~h}$ and lipid levels were quantified using the Oil Red O assay normalized to the protein amount measured by sulforhodamine B (SRB) assay. (A) Evaluation of steatosis in FFA-treated PHHs in comparison to control. Data are shown as the mean $+\mathrm{SD}, n=5$, paired t-test, $\left.p<0.01{ }^{* *}\right)$. (B) Microscopic evaluation of the lipid accumulation in representative PHH cultures (magnification $200 \times$ ), the scale bar is $10 \mu \mathrm{m}$.

\subsection{The Hepatocellular Steatosis Model Shows Only Mild Lipotoxic Effects}

Severe lipid accumulation can lead to lipotoxic effects and cell death. Therefore, we investigated whether FFA treatment leads to impaired cellular functions and cell loss. Pathological effects were evaluated by measurement of cell activity using XTT (2,3-bis(2-methoxy-4-nitro-5-sulfophenyl)-2H-tetrazolium-5-carboxanilid) assays, the ability to produce urea and impaired membrane integrity by measurement of LDH (lactate dehydrogenase) and AST (aspartate transaminase) release (Figure 2). Determination of cell activity showed no difference between FFA-treated PHHs and control cells, indicating comparable metabolic activity in both cultures (Figure 2A). Extracellular AST activity was significantly increased, whereas LDH activity showed an increase only by trend (Figure 2B,C). Determination of urea production showed no influence on metabolic capacities in the steatotic hepatocytes (Figure 2D). Taken together, the lipid accumulation in steatotic PHHs led to mild lipotoxic effects.

\subsection{Transcription of PPAR $\alpha$ Downstream Signaling Targets Is Increased in Steatosis}

NAFLD is characterized by changes in lipid homeostasis resulting in dysregulated lipid degradation, impaired FFA $\beta$-oxidation and augmented de novo lipogenesis [7-9]. In hepatocytes, PPAR $\alpha$ is a transcription factor responsible for the expression of target genes of lipid metabolism [11,12]. In contrast, SREBP-1c is a transcription factor that is responsible for the expression of lipogenesis genes [9]. Therefore, we analyzed the influence of in vitro lipid accumulation on key players in lipid homeostasis at the transcript level using RT-qPCR (Figure 3) and at the protein level using Western blot analyses (Figure 4). 
A

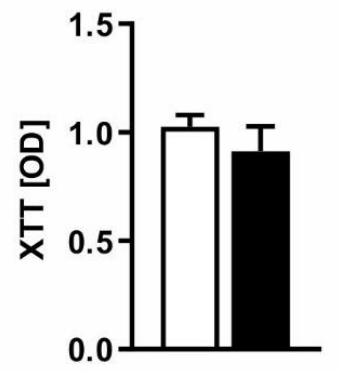

C

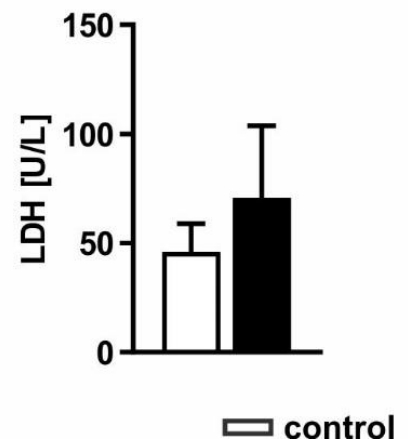

B

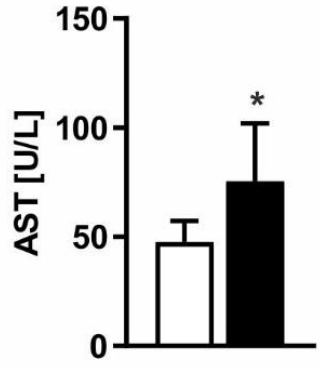

D

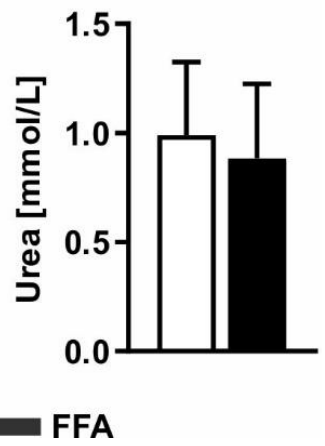

Figure 2. Evaluation of lipotoxicity on FFA-treated PHHs. PHHs were treated with 1 mM FFAs for 24 $\mathrm{h}$ and steatotic and control PHHs were investigated for $(\mathbf{A})$ cell activity measured by the conversion of XTT (2,3-bis-(2-methoxy-4-nitro-5-sulfophenyl)-2H-tetrazolium-5-carboxanilid); (B) enzyme activities of AST (aspartate transaminase) and (C) LDH (lactate dehydrogenase) determined in cell culture supernatants to evaluate disruptions of cell membrane integrity and (D) metabolic capacity examined by quantification of their urea production. Data are shown as the mean $+\mathrm{SD}, n=5$, paired t-test, $p<0.05(*)$

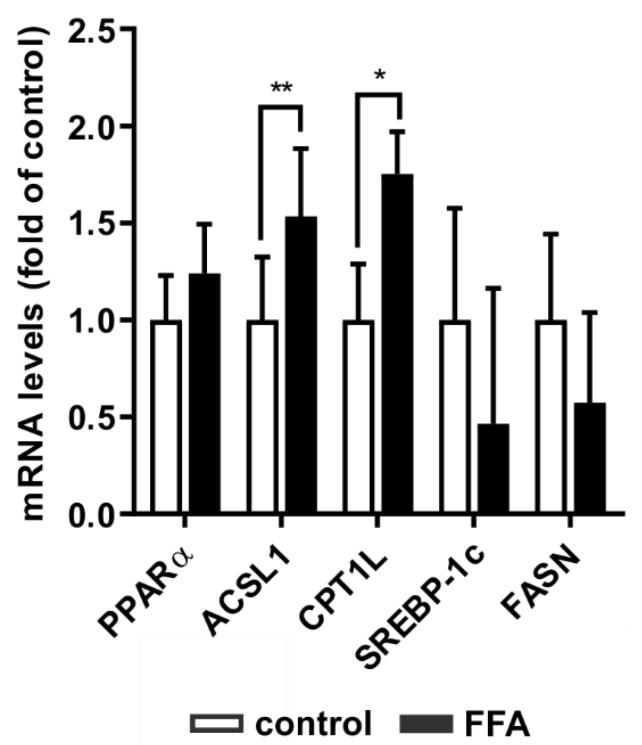

Figure 3. Adaption of gene expression of key players of lipid homeostasis in steatotic PHHs. PHHs were treated with $1 \mathrm{mM}$ FFAs for $24 \mathrm{~h}$ and relative mRNA expression levels of gene targets were determined using RT-qPCR. Investigation of genes centrally involved in lipid catabolism (PPAR $\alpha$, ACSL1 and CPT1L) and anabolism (SREBP-1c and FASN) in PHHs compared to control. Data are shown as the mean $+\mathrm{SD}, n=5$, paired t-test, statistical analyses were conducted on $\Delta \mathrm{C}_{\mathrm{T}}$ values, $p \leq 0.05\left(^{*}\right), p<0.01\left({ }^{* *}\right)$. 
A

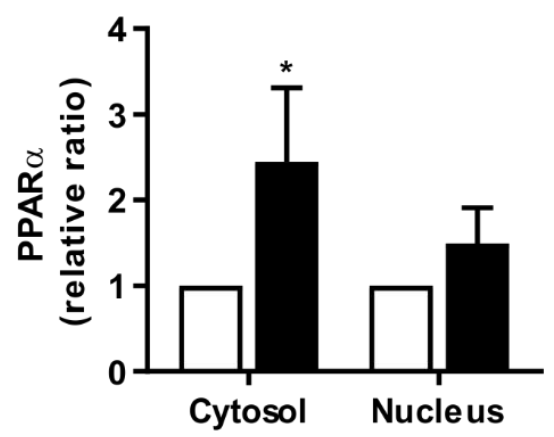

control

C

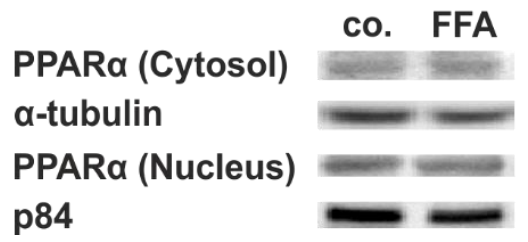

B

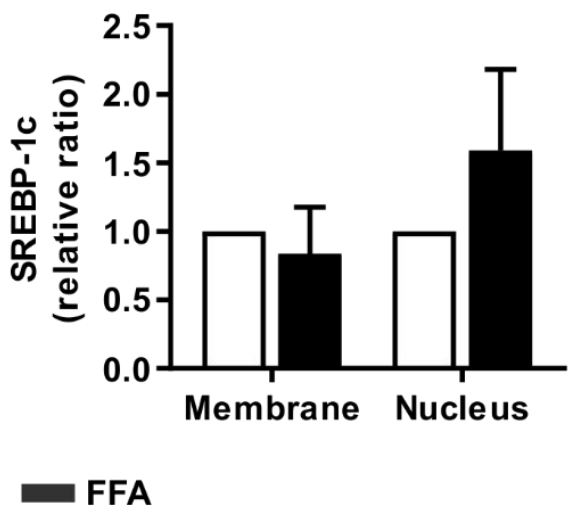

co. FFA

SREBP-1c (Membrane)
Na/K-ATPase
SREBP-1c (Nucleus)
p84

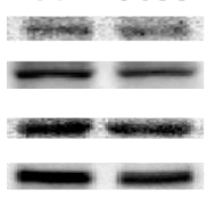

Figure 4. Activation of key signaling pathways in lipid homeostasis in steatotic hepatocytes. PHHs were treated with $1 \mathrm{mM}$ FFAs for $24 \mathrm{~h}$ and protein levels of PPAR $\alpha$ and SREBP-1c were investigated. Western blot analyses were performed after protein extraction from different subcellular fractions of FFA-treated PHHs and control. Densitometric measurements of (A) cytosolic PPAR $\alpha$ normalized to the expression levels of $\alpha$-tubulin, nucleic PPAR $\alpha$ normalized to p84, (B) ER membranebound SREBP-1c normalized to $\mathrm{Na}^{+} / \mathrm{K}^{+}$-ATPase and nucleic SREBP-1c normalized to $\mathrm{p} 84$ expression. Data are shown as the mean $+\mathrm{SD}, n=5$, paired t-test, $p \leq 0.05\left(^{*}\right)$. (C) Representative Western blot images show the specific bands of PPAR $\alpha$, $\alpha$-tubulin, p84, SREBP-1c, and $\mathrm{Na}^{+} / \mathrm{K}^{+}$-ATPase in control and steatotic PHHs.

The transcription factor PPAR $\alpha$ is a major mediator of fatty acid degradation. It induces the transcription of ACSL1 and CPT1L, two enzymes that catalyze necessary steps prior to fatty acid $\beta$-oxidation. FFA-treated hepatocytes showed increased mRNA levels of ACSL1 and CPT1L, while PPAR $\alpha$ mRNA showed only a slight tendency to increase (Figure 3). SREBP-1c and its transcription target FASN, both involved in fatty acid synthesis, did not show any statistically significant transcriptional changes. Thus, steatotic hepatocytes showed an adaption of lipid homeostasis towards catabolism, while promoters of de novo lipogenesis did not adjust to the increased lipid load.

\subsection{Steatotic Treatment Increases the Level of Cytosolic PPAR $\alpha$}

For validation of the transcript data at the protein level, we performed Western blot analyses. Additionally, we investigated whether increased levels of key signaling proteins correlate with a higher activation of these mediators. Therefore, the protein levels of the activated forms of PPAR $\alpha$ and SREBP-1c were measured.

PPAR $\alpha$ shuttles between the cytosol and nucleus, and its concentration in the latter is crucial for its action as a transcription factor [33]. After FFA treatment, the protein levels of PPAR $\alpha$ in both cellular compartments were determined relative to untreated PHHs. In both compartments, PPAR $\alpha$ showed higher levels in steatotic hepatocytes, but this increase was only significant for cytosolic PPAR $\alpha$ (Figure $4 \mathrm{~A}$ ).

The precursor form of SREBP-1c is bound to the endoplasmic reticulum (ER) membrane. Activation occurs through proteolytic cleavage. Cleaved SREBP-1c then translocates to the nucleus [34]. The protein levels of ER membrane-bound or nucleic SREBP-1c did not differ between the vehicle-treated and FFA-treated PHH groups (Figure 4B). Taken together, the protein data confirmed the transcript data. Additionally, we observed hints of 
increased activation of the metabolic pathway by activation of PPAR $\alpha$ and expression of its downstream targets.

\subsection{Genistein Administration Causes Hepatotoxicity Only in High Doses}

Genistein is a natural compound in soybean and is described as a PPAR $\alpha$ agonist [35]. Therefore, it can decrease hepatic lipid content by increasing lipid metabolism [29]. For evaluation of the toxic effects of genistein, it was administered to FFA- or vehicle-treated PHHs at different concentrations $(0,1,5,10,50$, and $100 \mu \mathrm{M})$. The cytotoxic effects of the substance were investigated by measuring cellular metabolic activity reflecting cell viability using the XTT assay and by analyzing LDH activity reflecting a decrease in membrane integrity due to cytotoxic effects. Genistein treatment demonstrated impaired cell viability in PHHs independent of FFA treatment at the highest administered genistein concentration of $100 \mu \mathrm{M}$ (Figure 5A). Nonetheless, the addition of genistein did not augment the release of LDH into the cell culture supernatant, as happens in necrosis or late apoptosis (Figure 5B). However, the induction of apoptosis at high concentrations could not be excluded, indicating that further results for $100 \mu \mathrm{M}$ genistein should be discussed critically.

A

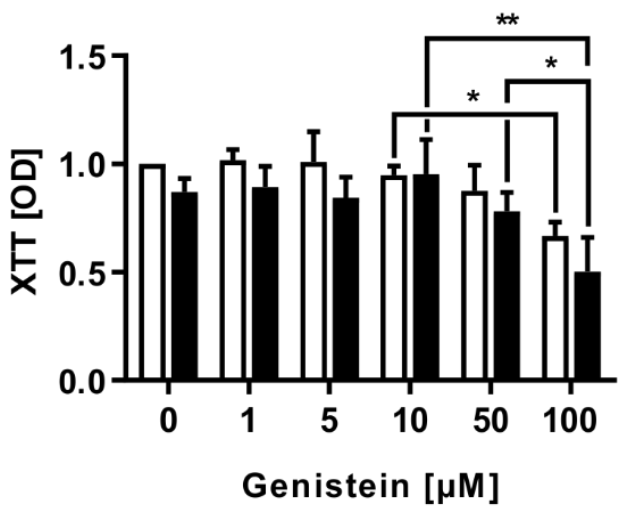

B

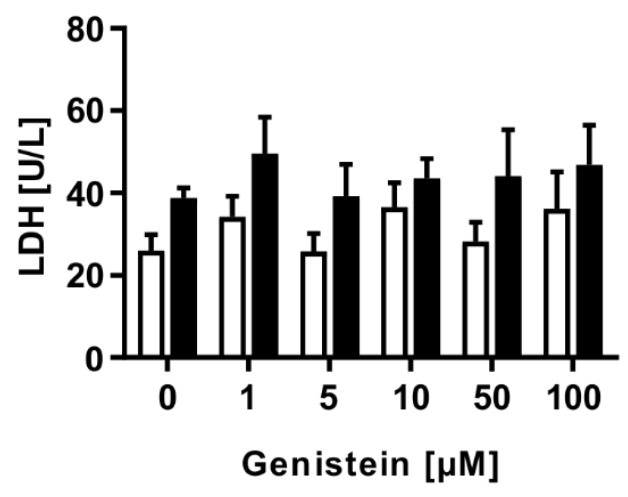

Genistein $[\mu \mathrm{M}]$

control

FFA

Figure 5. Evaluation of the cytotoxic effect of different concentrations of the soy isoflavone genistein on FFA-treated and control PHHs. PHHs were treated with $1 \mathrm{mM}$ FFAs for $24 \mathrm{~h}$, followed by $24 \mathrm{~h}$ of treatment with genistein $(0,1,5,10$, 50 , and $100 \mu \mathrm{M})$. Toxicity was measured by evaluation of (A) cell activity determined with the XTT (2,3-bis-(2-methoxy4-nitro-5-sulfophenyl)-2H-tetrazolium-5-carboxanilid) assay and (B) LDH (lactate dehydrogenase) release as a marker for impaired cell integrity. Data are shown as the mean $+\mathrm{SD}, n=3$, two-way ANOVA and post hoc Tukey or Sidak test, $p \leq 0.05\left({ }^{*}\right), p<0.01\left(^{* *}\right)$. Selected comparisons are shown; for details on the statistical evaluation, see Table S1A, Supplementary Materials.

\subsection{Genistein Induces PPAR Activation Only in Control PHHs}

Genistein acts as a PPAR $\alpha$ agonist [35]. Therefore, we tested the ability of genistein to influence lipid-associated signaling pathways. Treatment of control PHHs with genistein led to a concentration-dependent decrease in PPAR $\alpha$ mRNA expression, while no change in PPAR $\alpha$ expression in steatotic PHHs was observable (Figure 6Ai). Both PHH groups featured no further change in the mRNA levels of the transcriptional targets of PPAR $\alpha$ (Figure S1, Supplementary Materials). Only the highest genistein concentration of $100 \mu \mathrm{M}$, which had shown cytotoxic effects in the XTT assay (Figure 5A), led to a decrease in ACSL1 mRNA (Figure S1B). A concentration-dependent increase in PPAR $\alpha$ activation was observable in an increase in cytosolic and nuclear PPAR $\alpha$ protein in control PHHs (Figure 6Aii,Aiii). In contrast, PPAR $\alpha$ activation in steatotic PHHs was initially increased and showed no further rise that was dependent on the genistein dose. 
A

i

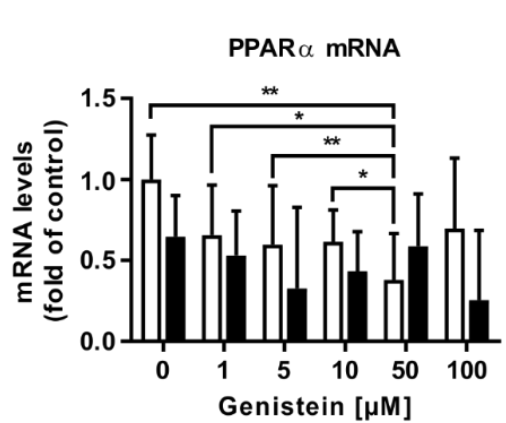

ii

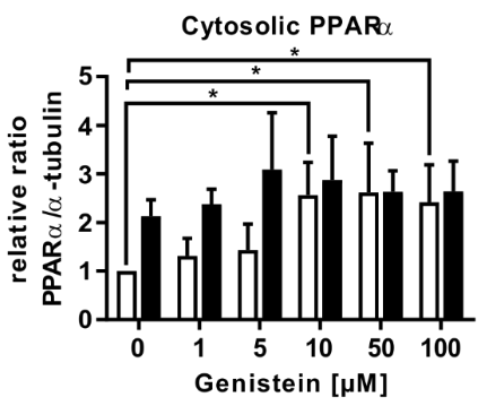

iii

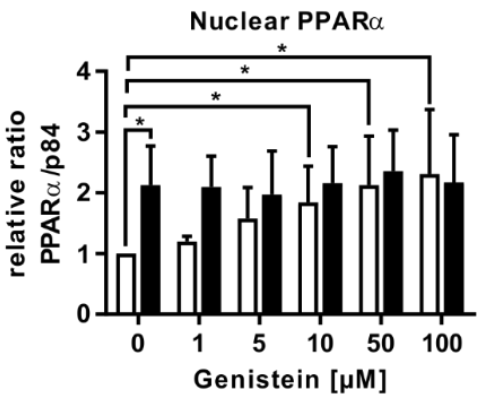

B

i

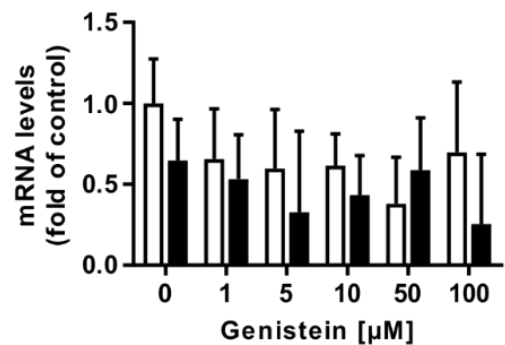

ii

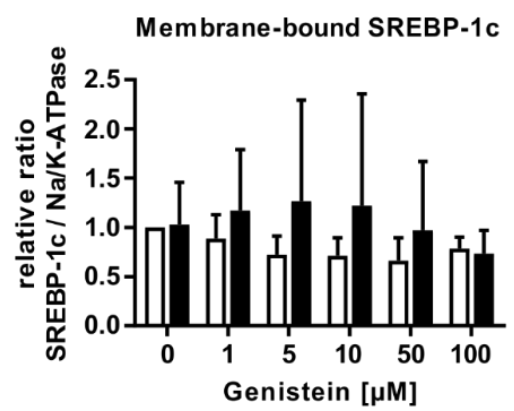

iii

Nuclear SREBP-1c

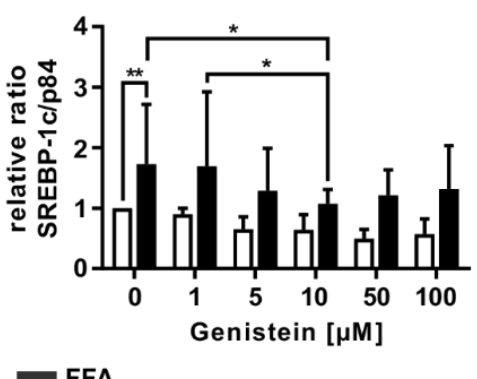

FFA

C

Genistein $[\mu \mathrm{M}]$

PPARa (Cytosol)

$\alpha$-tubulin

PPARa (Nucleus)

p84

SREBP-1c (Membrane)

$\mathrm{Na} / \mathrm{K}$-ATPase

SREBP-1c (Nucleus)

p84

$\square$ control

Figure 6. Transcriptional and translational response of genistein-treated steatotic PHHs on (A) PPAR $\alpha$ and (B) SREBP-1c, two central regulators of hepatic lipid homeostasis. PHHs were treated with $1 \mathrm{mM}$ FFAs for $24 \mathrm{~h}$, followed by $24 \mathrm{~h}$ of additive treatment with genistein $(0,1,5$, 10, 50, and $100 \mu \mathrm{M}$ ). (Ai) PPAR $\alpha$ mRNA levels were determined by RT-qPCR; (Aii) cytosolic and (Aiii) nucleic PPAR $\alpha$ protein levels were assessed by Western blot ( $\alpha$-tubulin and p84 served as the respective reference proteins). (Bi) Relative mRNA expression levels of SREBP-1c as measured by RT-qPCR; (Bii) densitometric measurements of ER membrane-bound SREBP-1c normalized to $\mathrm{Na}^{+} / \mathrm{K}^{+}$-ATPase and (Biii) nucleic SREBP-1c normalized to p84 expression. Data are shown as the mean $+\mathrm{SD}, n=5$ for RT-qPCR data, $n=4$ for Western blot measurements, two-way ANOVA with Tukey or Sidak post hoc test. $p \leq 0.05\left(^{*}\right), p<0.01\left(^{* *}\right)$. Selected comparisons are shown; for details on the statistical evaluation, see Table S1B, Supplementary Materials. (C) Representative Western blot images show the specific bands of PPAR $\alpha, \alpha$-tubulin, p84, SREBP-1c, and $\mathrm{Na}^{+} / \mathrm{K}^{+}$-ATPase in control and steatotic PHHs after genistein treatment. 
In regard to SREBP-1c mRNA and its downstream target FASN, no changes in its expression were observable due to genistein treatment (Figure 6Bi and Figure S1C). Notably, the concentration-dependent rise in the variation in the protein level of membrane-bound SREBP-1c suggests a highly donor-dependent effect on SREBP-1c expression (Figure 6Bii). However, SREBP-1c activity was decreased in genistein-treated steatotic hepatocytes, with a significant result for $10 \mu \mathrm{M}$ genistein (Figure 6Biii).

In summary, the PPAR $\alpha$ agonistic and thus steatosis-counteracting properties of genistein were only observed in control PHHs at the protein level. In contrast, a downregulation of fatty acid synthesis mediating SREBP-1c was only seen in steatotic PHHs, although only after treatment with $10 \mu \mathrm{M}$ genistein

\section{Discussion}

To date, the growing global disease burden of NAFLD has not been remedied by an adequate pharmaceutical treatment [36]. Complex mechanisms, including dyslipidemia, hyperinsulinemia and inflammation, drive the development of hepatic steatosis and fuel its progression up to the point of cirrhosis and end-stage liver disease [37]. Drugs currently used in NAFLD management only treat individual etiological factors that contribute to its onset and progression [24]. In addition, some of them, such as PPAR $\alpha$ agonistic fibrates, have been reported to exert hepatotoxicity themselves, which is a major drawback in NAFLD treatment [38]. The phytoestrogen genistein is a natural compound contained in soybean and has been described as a PPAR $\alpha$ agonist [35]. Epidemiological data conclude that a higher soy food intake is associated with a lower prevalence of NAFLD [39].

Therefore, this study aimed to investigate the potential of genistein as a therapeutic treatment to improve steatosis in humans.

\subsection{Induction of Steatosis Is Accompanied by Mild Lipotoxic Effects}

The applied in vitro model, using oleate and palmitate in a 2:1 ratio, aims at the imitation of benign chronic steatosis [40]. As intended, treatment of PHHs with FFAs led to considerable intracellular lipid accumulation, which is in line with findings of our group and others $[40,41]$. This increased intracellular lipid content did not lead to substantial lipotoxic effects. Only one of the four different parameters that we evaluated as indicators of cell viability showed a significant response. The extracellular enzymatic activity of AST was slightly increased in steatotic hepatocytes. Transaminase measurements are a common way to assess liver injury in clinical and experimental settings. As this readout shows primarily a disturbance in membrane integrity very sensitively, a slight elevation in the context of cell viability has to be interpreted carefully. Instead, the determination of further hepatic viability parameters, such as metabolic competency via urea measurement and of cell activity via the tetrazolium salt assay, has been shown to yield a more comprehensive result for cell viability [42]. Induction of steatosis did not lead to alterations in those two parameters, as was already reported by our group [41].

3.2. FFA-Treated PHHs Exhibit Changes in Lipid Catabolism and Anabolism Pathways Analogous to the First Stages of NAFLD

The nuclear transcription factor PPAR $\alpha$ is a key regulator of hepatic lipid degradation. It is activated by diverse exogenous and endogenous ligands, i.e., dietary fatty acids such as oleate and palmitate $[12,43]$. Other cell culture experiments conducted with PHHs or hepatic cell lines revealed an upregulation of PPAR $\alpha$ or its transcription target CPT1L after $24 \mathrm{~h}$ of FFA treatment [44,45]. Our study confirms that FFA treatment of PHHs resulted in PPAR $\alpha$ activation, as seen by an increase in the cytosolic protein and the PPAR $\alpha$ transcription targets ACSL1 and CPT1L. This effect was even more enhanced $24 \mathrm{~h}$ later, when the steatotic hepatocytes without genistein treatment also showed a significant increase in the nucleic PPAR $\alpha$ protein (Figure 6Aiii). ACSL1 and CPT1L encode proteins involved in the preliminary steps of FFA breakdown by mitochondrial $\beta$-oxidation [15]. These processes reflect the hepatocytes' intention to reduce the escalated intracellular lipid load. 
A further physiological requirement to limit lipid storage is the downregulation of de novo lipogenesis. Unsaturated fatty acids regulate SREBP-1c, a major transcription factor in lipid synthesis, not only at the transcriptional level but also by accelerating its mRNA turnover and restricting the proteolytic processing of the protein. Proteolytic cleavage of the ER membrane-bound precursor is suppressed, thus reducing the release of the active nuclear SREBP-1c isoform and diminishing its transcriptional activity [46]. After $24 \mathrm{~h}$ of FFA treatment, we observed a slight but insignificant decrease in the mRNA levels of SREBP-1c and FASN in the steatotic PHHs compared to the control. In contrast to the decrease in SREBP-1c mRNA, we observed an insignificant increase in the activated SREBP-1c protein, which became significant $24 \mathrm{~h}$ later in steatotic hepatocytes that were not supplemented with genistein (Figure 6Biii). An insignificant increase in FASN transcription is in line with SREBP-1c activation but vanishes with donor variances. Investigations on HepG2 cells incubated under comparable conditions of FFA treatment, although for $14 \mathrm{~h}$, resulted in similar SREBP-1c and FASN expressions to those observed by us, thus indicating a gradual change in their trend of expression from short-term to long-term incubation times as also suggested by us [47]. Studies on human liver biopsies have reported increased SREBP-1c expression in samples from NAFLD patients [18]. Reduced PPAR $\alpha$ expression is documented in liver biopsies featuring NASH or fibrosis, while those of simple steatotic livers do not differ from healthy liver tissue [48]. In our model of benign steatosis, we did not detect changes in PPAR $\alpha$ mRNA levels, although a slight decrease in PPAR $\alpha$ mRNA after $48 \mathrm{~h}$ was observable. The reasons for the pathologic changes in lipogenic signaling observed in NAFLD liver samples are not fully understood [48]. A possible explanation may lie in the stress signaling. FFA overload induces oxidative and ER stress in hepatocytes. A recently published study by our group has shown that ER stress is even more pronounced under steatotic conditions [41], which in turn induces cleavage of SREBP-1c [49].

Overall, our data suggest that regulatory mechanisms to adapt metabolism to different levels of lipid accumulation work on different time scales. A study on mice fed a Western diet reported that mitochondrial adaptation in hepatocytes of steatotic animals required several weeks [50]. Since mitochondria are the key site of fatty acid degradation, long-term negative effects on PPAR $\alpha$-regulated processes are a logical consequence of persistent substrate overload. When using PHHs, the initial lipid load of the cells, which is dependent on the pre-existing hepatic steatosis of the donor, also has to be taken into account [41]. As shown by our group, hepatocytes initially containing high lipid levels displayed a long-ranging decrease in mitochondrial activity. Structural and functional impairments of mitochondria are proven consequences of hepatic steatotis [51].

\subsection{Genistein Shows Hepatotoxic Effects at High Concentrations}

Genistein is a naturally occurring isoflavone that has shown beneficial effects on lipid homeostasis. On the one hand, many of genistein's positive properties are ascribed to its antioxidative capacities [27]. On the other hand, it can cause oxidative genetic damage itself. In colon carcinoma cells, $100 \mu \mathrm{M}$ genistein induced DNA strand breaks [52]. In our assessment of genistein-induced hepatotoxicity, we observed a decreased cell viability at this concentration. Other groups, however, did not observe any impairment in cell viability after treatment with up to $100 \mu \mathrm{M}$ in the human hepatoma cell line HepG2 [53,54], possibly due to a stronger resilience of the immortalized cell line. Another recent publication reported repeated viability assessments of genistein-treated HepG2 cells [55]. Here, no cytotoxic effect was seen after incubation with $100 \mu \mathrm{M}$ for $24 \mathrm{~h}$, but this became obvious after $48 \mathrm{~h}$ of incubation [55].

\subsection{Genistein Acts as a PPAR $\alpha$ Agonist Only in Nonsteatotic PHHs}

Thus far, research on the beneficial effects of genistein in the context of NAFLD has mainly been conducted as in vivo experiments in rodents [30]. Some clinical data are available on genistein-treated patients featuring NAFLD or metabolic syndrome, indicating a balancing effect on lipid metabolism [56]. 
Genistein has been shown to be a PPAR $\alpha$ agonist [53]. In our analyses, PHH incubation with the isoflavone led to a decrease in PPAR $\alpha$ mRNA expression. A study on high-fat diet-fed mice also reported a tendency towards reduced PPAR $\alpha$ mRNA levels after genistein treatment [57]. In contrast, our investigations showed a dose-dependent induction of PPAR $\alpha$ protein expression. This effect was restricted to control PHHs, suggesting that FFA-treated PHHs differ in their susceptibility to PPAR $\alpha$ stimulation. The steatotic PHHs already exhibited an upregulation of PPAR $\alpha$ protein, which could not be further ameliorated by the addition of genistein. Asrih et al. made comparable observations after treatment of HepG2 cells with the metabolic regulator fibroblast growth factor 21 (FGF21) [58]. Individual incubation with either FFAs or FGF21 increased fatty acid oxidation and the mRNA level of the PPAR $\alpha$ downstream target CPT1L. Upon simultaneous administration of FFAs and FGF21, HepG2 cells exhibited a similar response but no further increase, which was explained by a potential loss of FGF21 action in the presence of FFAs. The complex mechanisms regulating PPAR $\alpha$ activation and turnover are still the subject of intense research [59]. There is increasing evidence on post-translational regulation of PPAR $\alpha$ by miRNAs, which in turn are dysregulated in steatotic hepatocytes [60]. It was further shown that PPAR $\alpha$ ligands are capable of preventing ubiquitination and subsequent degradation of the nuclear receptor via the proteasome [61]. Thus, one possible explanation for elevated protein levels despite reduced mRNA levels in the presence of genistein might be a prolongation of the PPAR $\alpha$ protein half-life accompanied by an inhibition of its ligand-activated transcriptional capacity.

\subsection{In Steatotic PHHs, Genistein Leads to the Downregulation of Activated SREBP-1c}

Rodent in vitro and in vivo NAFLD models show a reversal of steatosis-induced SREBP1-c protein upregulation after treatment with genistein [29,62]. Additionally, in the human hepatoma cell line HepG2, genistein treatment reduces SREBP-1c protein, whereas its mRNA level is not affected. Since the ratio of mature to immature SREBP1c was shown to decline, it was proposed that genistein reduces SREBP-1c proteolytic cleavage [63]. Our investigations confirm the ability of genistein at a dose of $10 \mu \mathrm{M}$ to attenuate the upregulation of cleaved SREBP-1c in steatotic hepatocytes. In the control PHHs, genistein did not lead to a significant decrease in SREBP-1c protein. Transcription of FASN was not affected either. In the abovementioned NAFLD models with genistein administration, isoflavone treatment was conducted in parallel with the induction of steatosis. In our experimental setting, however, steatosis was first induced and then genistein was administered on steatotic cells. It might therefore be possible that further consequences of the treatment become visible after a prolonged observation period.

\subsection{In Steatotic Hepatocytes, Genistein Suppresses De Novo Lipogenesis, While Genistein-Mediated Induction of Hepatic Lipid Degradation Is Abrogated}

In summary, our data show that the in vitro model utilizing PHHs serves as a realistic approach for the study of early NAFLD development. FFA treatment activated $\beta$-oxidation, which could be observed by elevated PPAR $\alpha$ protein levels and a subsequent increase in CPT1L and ACSL1 transcription. A similar induction of PPAR $\alpha$ protein was also achieved by genistein treatment, but only in nonsteatotic PHHs. Conversely, the examined PPAR $\alpha$ transcription targets were not influenced by genistein, and PPAR $\alpha$ mRNA was even reduced. Considering the current literature on $\operatorname{PPAR} \alpha$, we hypothesize that these diverging observations might be due to a stabilizing effect of the PPAR $\alpha$ ligand genistein on the protein while simultaneously interfering with its ligand-activated transcription capacity. These responses were only present in nonsteatotic PHHs. Former FFA treatment abolished the genistein effect on PPAR $\alpha$. In contrast, abrogation of the de novo lipogenesis pathway via genistein-mediated suppression of SREBP-1c activation was only seen in steatotic hepatocytes. Long-term steatotic conditions in vivo lead to aberrations in the PPAR $\alpha$ and SREBP-1c pathways $[18,48,64]$. Such changes were also confirmed in shortterm in vitro investigations $[29,64]$. Our current and former observations, however, imply that the molecular manifestations of hepatic steatosis as seen in PHHs are not as fast-paced 
as those reported for hepatic cell line experiments. We have shown that the rate of lipid accumulation in PHHs depends on the initial lipid load and subsequently reaches a steady state [41]. Whether genistein can then interfere with and reverse the downregulation of PPAR $\alpha$ would be an interesting matter for future studies on PHHs. Overall, we can confirm that genistein exerts beneficial effects on different levels of hepatic lipid metabolism and could thus be a promising drug candidate for NAFLD prevention and therapy.

\subsection{Limitations}

The strengths and limitations of our study are closely intertwined. Among the various monocellular in vitro models to study liver function and pathologies, PHHs are closest to the conditions found in reality. However, the cellular response in culture depends on the former health status of the donor, which is why PHHs do not behave as homogeneously as immortalized cell lines. In the present study, this circumstance is reflected by the fact that several results are associated with high standard deviations. Furthermore, the protocol for hepatocyte isolation requires a sufficiently large liver specimen; thus, sample material from surgical patients is scarce, and the number of biological replicates is limited.

Aside from that, several of our results suggest a time-dependent effect of the FFA treatment on the signaling pathways of PPAR $\alpha$ and SREBP-1c. Yet, this study was not designed as a time course experiment and cannot provide sufficient insight into the question of time dependency. A study focusing on the time course of FFA-induced changes in PPAR $\alpha$ and SREBP-1c signaling will therefore be a future goal of our group.

\section{Materials and Methods}

\subsection{Isolation of Primary Human Hepatocytes}

Liver tissues for hepatocyte isolation were obtained after informed consent was obtained from patients undergoing liver surgery at the Department of General, Visceral and Transplantation Surgery at Charité University Medicine Berlin, Germany. The study was conducted according to the Declaration of Helsinki and received prior approval from the local ethics committee (Charité University Medicine Berlin, registration number EA2/076/09, date 28 July 2019). Tissue samples were freshly retrieved from macroscopically tumor-free areas of the resected livers. Samples with infections with hepatitis B virus, hepatitis $C$ virus or human immunodeficiency virus or higher grades of liver cirrhosis (Child-Pugh class B or C) were excluded. Isolation of PHHs was performed as previously described $[65,66]$. In brief, PHHs were isolated in a two-step EGTA/collagenase perfusion technique. After isolation, PHHs were pooled, washed with phosphate buffered saline (PBS; PAA Laboratories, Pasching, Austria) and subjected to density gradient centrifugation for $20 \mathrm{~min}$ at $1280 \mathrm{~g}$ at $4{ }^{\circ} \mathrm{C}$ using Percoll (Biochrom AG, Berlin, Germany). The resulting cell pellet was washed, and the cells were resuspended in PHH culture medium (Williams Medium E, $100 \mathrm{U} / 100 \mu \mathrm{M}$ penicillin/streptomycin, $1 \mathrm{mM}$ sodium pyruvate, $15 \mathrm{mM}$ HEPES, 10\% fetal bovine serum (FBS), 1\% nonessential amino acids (MEM NEAA; all provided by Gibco Invitrogen, Karlsruhe, Germany), $1.6 \mu \mathrm{M}$ dexamethasone (Fortecortin ${ }^{\circledR}$, Merck, Darmstadt, Germany), and $1 \mathrm{mM}$ human insulin (Sanofi-Aventis, Frankfurt a.M., Germany)) and seeded on cell culture plates at a density of 100,000 viable cells $/ \mathrm{cm}^{2}$. The cell culture plates were previously coated with type I collagen that was prepared from rat tails in our own laboratory according to the protocol of Rajan et al. [67].

\subsection{Cell Culture, In Vitro Induction of Steatosis and Genistein Treatment}

$\mathrm{PHH}$ adherence was achieved overnight in $\mathrm{PHH}$ culture medium at $37{ }^{\circ} \mathrm{C}$, and steatosis was induced according to the in vitro steatosis model described by GómezLechón et al. [40]. PHH culture medium was replaced by control (Williams Medium E, $100 \mathrm{U} / 100 \mu \mathrm{M}$ penicillin/streptomycin, $1 \mathrm{mM}$ sodium pyruvate, $15 \mathrm{mM}$ HEPES, 5\% FBS, $1 \%$ MEM NEAA supplemented with $0.3 \%$ methanol), or FFA-containing medium (control medium supplemented with $1 \mathrm{mM}$ oleate/palmitate in a 2:1 ratio (Gibco Invitrogen, Karlsruhe, Germany) in methanol (J.T. Baker, Deventer, The Netherlands)) and hepatocytes 
were cultured for $24 \mathrm{~h}$. For genistein treatment, the respective cells were further incubated with control medium supplemented with $0,1,5,10,50$, or $100 \mu \mathrm{M}$ genistein (Roth, Karlsruhe, Germany) for another $24 \mathrm{~h}$. Genistein was dissolved in dimethyl sulfoxide (DMSO, Sigma-Aldrich, Steinheim, Germany) and diluted with low FBS-PHH culture medium to the final concentrations (with a final DMSO concentration of $0.5 \%$ ).

\subsection{Evaluation of Steatosis by Oil Red O and Sulforhodamine B (SRB) Staining}

Intracellular lipid accumulation was evaluated by staining with the diazo dye Oil Red O (Sigma Aldrich, Steinheim, Germany), which stains neutral lipids. Before staining, the hepatocytes were washed with PBS and fixed for $30 \mathrm{~min}$ with $3.7 \%$ formaldehyde (Herbeta Arzneimittel, Berlin, Germany). Cells were incubated with Oil Red O working solution (8.6 mM Oil Red $\mathrm{O}$ in isopropanol, diluted in $\mathrm{dH}_{2} \mathrm{O}$ in a 3:2 ratio) for at least $20 \mathrm{~min}$. Unfixed dye was removed by thorough washing with tap water, and cells were dried at room temperature. Then, Oil Red O dye was dissolved from the cells with isopropanol (Roth, Karlsruhe, Germany), and the absorbance was measured at $492 \mathrm{~nm}$ with a spectral photometer (Fluostar Optima, BMG, Offenburg, Germany).

To calculate lipid content relative to cell count, SRB (Sigma Aldrich, Steinheim, Germany) protein staining followed the Oil Red O assay. SRB binds to protonated amino acids. The fixed hepatocytes were washed with PBS and incubated with SRB solution $(0.4 \%$ $(\mathrm{m} / \mathrm{v}))$ for $30 \mathrm{~min}$. Unbound SRB dye was removed by thorough washing with acetic acid $(1 \%(v / v)$, Merck, Darmstadt, Germany). A 10 min incubation with $10 \mathrm{mM}$ Tris solution dissolved the bound SRB. Absorbance was measured with a spectral photometer at $580 \mathrm{~nm}$.

\subsection{XTT Assay}

Cell viability was assessed using the Cell Proliferation Kit II (XTT; Roche Diagnostics, Mannheim, Germany) according to the manufacturer's instructions. The yellowish tetrazolium salt XTT (2,3-bis-(2-methoxy-4-nitro-5-sulfophenyl)-2H-tetrazolium-5-carboxanilid) is converted in the mitochondria of viable cells to orange formazan. In brief, XTT labeling reagent was mixed with XTT electron-coupling reagent in a 50:1 ratio. Fifty microliters of the mixture were added to each well of a 96-well plate, followed by incubation for $24 \mathrm{~h}$. Absorbance was measured at $492 \mathrm{~nm}$ using a spectral photometer.

\subsection{LDH, AST and Urea Assays}

Lactate dehydrogenase (LDH) and aspartate aminotransferase (AST) are intracellular enzymes that are released upon cell membrane damage. To evaluate membrane integrity, the enzymatic activity of LDH and AST was measured in the cell culture supernatant utilizing Fluitest ${ }^{\circledR}$ reaction kits (Analyticon, Lichtenfels, Germany).

Urea is the end product of amino acid catabolism and results from the conversion of toxic ammonia in the urea cycle, which occurs mainly in the liver. Therefore, the metabolic activity of hepatocytes can be assessed by the amount of urea released into the cell culture supernatant. The urea concentration was measured with a Fluitest ${ }^{\circledR}$ reaction kit.

All three assays were performed according to the manufacturer's protocol. Absorbance was measured at $340 \mathrm{~nm}$ with a spectral photometer.

\subsection{RT-qPCR Analyses}

Messenger RNA expression levels of PPAR $\alpha$, SREBP-1c, ACSL1, CPT1L, and FASN were analyzed by RT-qPCR. Total RNA was isolated from hepatocytes by Trizol ${ }^{\circledR}$ (Invitrogen, Karlsruhe, Germany) extraction according to the manufacturer's protocol. RNA concentrations were determined with a spectral photometer (Nanodrop ND-1000, Peqlab, Erlangen, Germany) after resuspension with $50 \mu \mathrm{L}$ diethylpyrocarbonate (DEPC) $\mathrm{H}_{2} \mathrm{O}$ (Roth, Karlsruhe, Germany). Only samples with an A260/A280 ratio of at least 1.9 were processed further. If subsequent experiments were not performed immediately, the samples were stored at $-80^{\circ} \mathrm{C}$. 
Reverse transcription was conducted with the cDNA Synthesis Kit by Fermentas (St. Leon-Rot, Germany) adhering to the manufacturer's protocol. The kit utilizes Oligo(dT) $)_{18}$ primers. For each reaction, $1 \mu \mathrm{g}$ total RNA was used. The cycling profile used in the Veriti ${ }^{\mathrm{TM}}$ 96-well thermocycler (Applied Biosystems, Foster City, CA, USA) is detailed in Table 1. The samples were immediately processed further or stored at $-20^{\circ} \mathrm{C}$ for a maximum of $14 \mathrm{~d}$.

Table 1. Thermocycling profile of the reverse transcription reaction.

\begin{tabular}{ccc}
\hline Step & Temperature $\left({ }^{\circ} \mathbf{C}\right)$ & Time $(\mathbf{m i n})$ \\
\hline Annealing & 65 & 5 \\
Reverse transcription & 37 & 60 \\
Inactivation & 70 & 5 \\
\hline
\end{tabular}

qPCR was performed with a Step One Plus Real Time PCR Cycler (Applied Biosystems, Foster City, CA, USA) with 50 ng cDNA used for each reaction. Specific hydrolysis probes for the PPAR $\alpha$, SREBP-1c, ACSL1, CPT1L, and FASN genes and TaqMan ${ }^{\circledR}$ Gene Expression Master Mix were purchased from Applied Biosystems (Foster City, CA, USA). The $\beta$-actin gene (ACTB) served as the reference gene. Assay details are listed in Table 2. All samples were measured in duplicates. The qPCR reaction profile is detailed in Table 3. Relative gene expression was calculated using the comparative $C_{T}$ method ( $2^{-\Delta \Delta C T}$ method).

Table 2. TaqMan ${ }^{\circledR}$ gene expression assays (Applied Biosystems, Foster City, CA, USA) applied for qPCR.

\begin{tabular}{ccc}
\hline Gene Symbol & Gene Name & Assay ID \\
\hline PPARA & Peroxisome proliferator activated receptor alpha & Hs00947539_m1 \\
SREBP-1c & Sterol regulatory element binding transcription factor 1 (SREBF1) & Hs01088691_m1 \\
CPT1L & Carnitine palmitoyltransferase 1A (CPT1A) & Hs00912671_m1 \\
ACSL1 & Acyl-CoA synthetase long-chain family member 1 & Hs00242530_m1 \\
FASN & Fatty acid synthase & Hs01005622_m1 \\
ACTB & Actin beta & Hs99999903_m1 \\
\hline
\end{tabular}

Table 3. qPCR thermocycling conditions.

\begin{tabular}{cccc}
\hline Step & Temperature $\left({ }^{\circ} \mathbf{C}\right)$ & Time $($ min:s) & Cycles \\
\hline UNG $^{1}$ incubation & 50 & $2: 00$ & 1 \\
Polymerase activation & 95 & $10: 00$ & 1 \\
Denaturation & 95 & $0: 15$ & 40 \\
Annealing/extension & 60 & $1: 00$ & \\
\hline
\end{tabular}

${ }^{1}$ Uracil-N-glycosylase.

\subsection{Western Blot Analyses}

Proteins were extracted utilizing the Subcellular Protein Fractionation Kit by Thermo Scientific (Rockford, IL, USA). To each cell culture dish containing approximately $2.1 \times 10^{6}$ viable PHHs, $200 \mu \mathrm{L}$ of cytosolic extraction buffer was added. The subsequent steps followed the manufacturer's instructions, resulting in distinct fractions of cytoplasmic, membrane-bound and nuclear soluble protein extractions for each sample. For protein quantification, the bicinchoninic acid assay (BCA; Interchim, Montelucon, France) was used according to the manufacturer's protocol. Samples were adjusted to a protein quantity of $1.2 \mu \mathrm{g} / \mu \mathrm{L}$ with $\mathrm{dH}_{2} \mathrm{O}$ and $20 \%$ sample buffer ( $0.4 \mathrm{M}$ Tris base, $10 \%$ SDS, $50 \%$ glycerol, $0.025 \%$ bromphenol blue and 25\% mercaptophenol, all from Sigma-Aldrich, Steinheim, Germany) and incubated at $100{ }^{\circ} \mathrm{C}$ for $5 \mathrm{~min}$. For each sample, $30 \mu \mathrm{g}$ protein was separated at a continuous voltage of $120 \mathrm{~V}$ on an $8 \%$ SDS-polyacrylamide gel. Then, protein transfer to a nitrocellulose membrane (Bio-Rad Laboratories Inc., Munich, Germany) was carried out with a tank blotting system (Mini Trans-Blot ${ }^{\circledR}$ Cell and Module; Bio-Rad Laboratories Inc., Munich, Germany) applying an electric current of $340 \mathrm{~mA}$ for $60 \mathrm{~min}$. After staining of 
the protein bands with Ponceau S solution (5 g Ponceau S in $75 \mathrm{~g}$ trichloroacetic acid (both by Merck, Darmstadt, Germany) and $75 \mathrm{~g}$ sulfosalicyclic acid (Sigma-Aldrich, Steinheim,

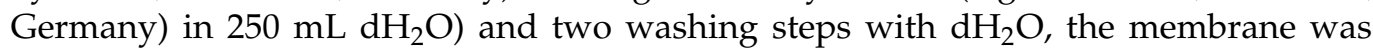
blocked with 5\% nonfat dry milk (Applichem, Darmstadt, Germany) in TBST (0.1\% Tween 20 (Merck, Darmstadt, Germany) in 20\% TBS (50 mM Tris base (Sigma-Aldrich, Steinheim, Germany) and $150 \mathrm{mM}$ sodium chloride (Merck, Darmstadt, Germany) in $\mathrm{dH}_{2} \mathrm{O}$ at $\mathrm{pH}$ 7.5) by continuously shaking for $1 \mathrm{~h}$ at room temperature. Afterwards, the membrane was washed with TBST and incubated with specific primary antibodies against PPAR $\alpha$, SREBP-1c, $\alpha$-tubulin, p84, or Na ${ }^{+} / \mathrm{K}^{+}$-ATPase at $4{ }^{\circ} \mathrm{C}$. p 84 served as a reference protein for nucleic PPAR $\alpha$ or SREBP-1c, $\alpha$-tubulin as a reference protein for cytosolic PPAR $\alpha$ and $\mathrm{Na}^{+} / \mathrm{K}^{+}$-ATPase for ER membrane-bound SREBP-1c. Four washing steps with TBST were followed by incubation with the secondary antibodies at RT. Antibodies were diluted in TBST and $1 \%(v / v)$ bovine serum albumin (BSA; Sigma-Aldrich, Steinheim, Germany). Further details on the primary and secondary antibodies are listed in Table 4. Prior to detection, the membrane was again washed four times with TBST and then incubated with ECL ${ }^{\mathrm{TM}}$ Detection Reagents (Sigma-Aldrich, Steinheim, Germany) according to the manufacturer's instructions. Chemiluminescence was detected with a VersaDoc Model 4000 (Bio-Rad Laboratories Inc., Munich, Germany).

Table 4. Antibodies for Western blotting.

\begin{tabular}{ccc}
\hline Antibody (Manufacturer) & Dilution & Incubation Time \\
\hline Mouse PPAR $\alpha$ (Dianova, Hamburg, Germany) & $1: 1000$ & Overnight \\
Mouse SREBP-1c (Biozol, Eching, Germany) & $1: 200$ & $2 \mathrm{~h}$ \\
Mouse $\alpha$-tubulin (Sigma-Aldrich, Steinheim, Germany) & $1: 2000$ & $1 \mathrm{~h}$ \\
Mouse p84 (Abcam, Cambridge, UK) & $1: 2000$ & $1 \mathrm{~h}$ \\
Rabbit $\mathrm{Na}^{+} / \mathrm{K}^{+}$-ATPase (Cell Signaling, Danvers, MA, USA) & $1: 1000$ & $1 \mathrm{~h}$ \\
Sheep anti-mouse (Amersham, Freiburg, Germany) & $1: 4000$ & $1 \mathrm{~h}$ \\
Donkey anti-rabbit & $1: 4000$ & $1 \mathrm{~h}$ \\
\hline
\end{tabular}

\subsection{Statistical Analyses}

Values are expressed as the mean $+\mathrm{SD}$. Each value represents the mean of at least three biological replicates. GraphPad Prism 7 (San Diego, CA, USA) was employed for significance analyses and chart design. Significant differences between single values were analyzed by a paired $\mathrm{t}$-test. For significance testing among multiple groups, a repeated measures two-way ANOVA (with the two factors of genistein treatment and steatotic treatment) was employed followed by post hoc tests to correct for multiple comparisons (Tukey test for the comparison of genistein treatment among steatotic and nonsteatotic PHHs or Sidak correction for differences between the steatotic and nonsteatotic groups treated with the same genistein dose). Statistical significance was assumed at $p \leq 0.05$.

Supplementary Materials: The following are available online, Figure S1: Evaluation of the effect of genistein on the transcriptional targets of PPAR $\alpha$ and SREBP-1c in steatotic PHHs, Table S1: Details on statistics for Figure 5, Figure 6 and Figure S1.

Author Contributions: Conceptualization, D.S. and G.D.; data curation, L.S., A.K. and V.K.-H.; formal analysis, L.S. and G.D.; funding acquisition, D.S. and G.D.; investigation, A.K.; methodology, G.D.; project administration, G.D.; resources, D.S.; supervision, D.S. and G.D.; validation, L.S. and G.D.; visualization, L.S.; writing — original draft, L.S. and G.D.; writing—review and editing, A.K., V.K.-H. and D.S. All authors have read and agreed to the published version of the manuscript.

Funding: The study was supported by the Federal Ministry of Education and Research (BMBF, Germany) within the research network Virtual Liver Network (VLN) [grant number: BMBF 0315741] and partly funded with tax money approved by the delegates of the Saxonian state parliament. We acknowledge support from Leipzig University for Open Access Publishing. 
Institutional Review Board Statement: The study was conducted according to the guidelines of the Declaration of Helsinki and approved by the Ethics Committee of Charité University Medicine Berlin (registration number EA2/076/09, date 28 July 2019).

Informed Consent Statement: Informed consent was obtained from all subjects involved in the study.

Data Availability Statement: The data presented in this study are available on request from the corresponding author. The data are not publicly available due to data protection regulations.

Acknowledgments: We cordially thank Anja Schirmeier at Charité Berlin for excellent technical assistance, Sebastian Lünse and the team from Charité University Medicine for the fruitful collaboration.

Conflicts of Interest: The authors declare no conflict of interest. The funders had no role in the design of the study; in the collection, analyses, or interpretation of data; in the writing of the manuscript, or in the decision to publish the results.

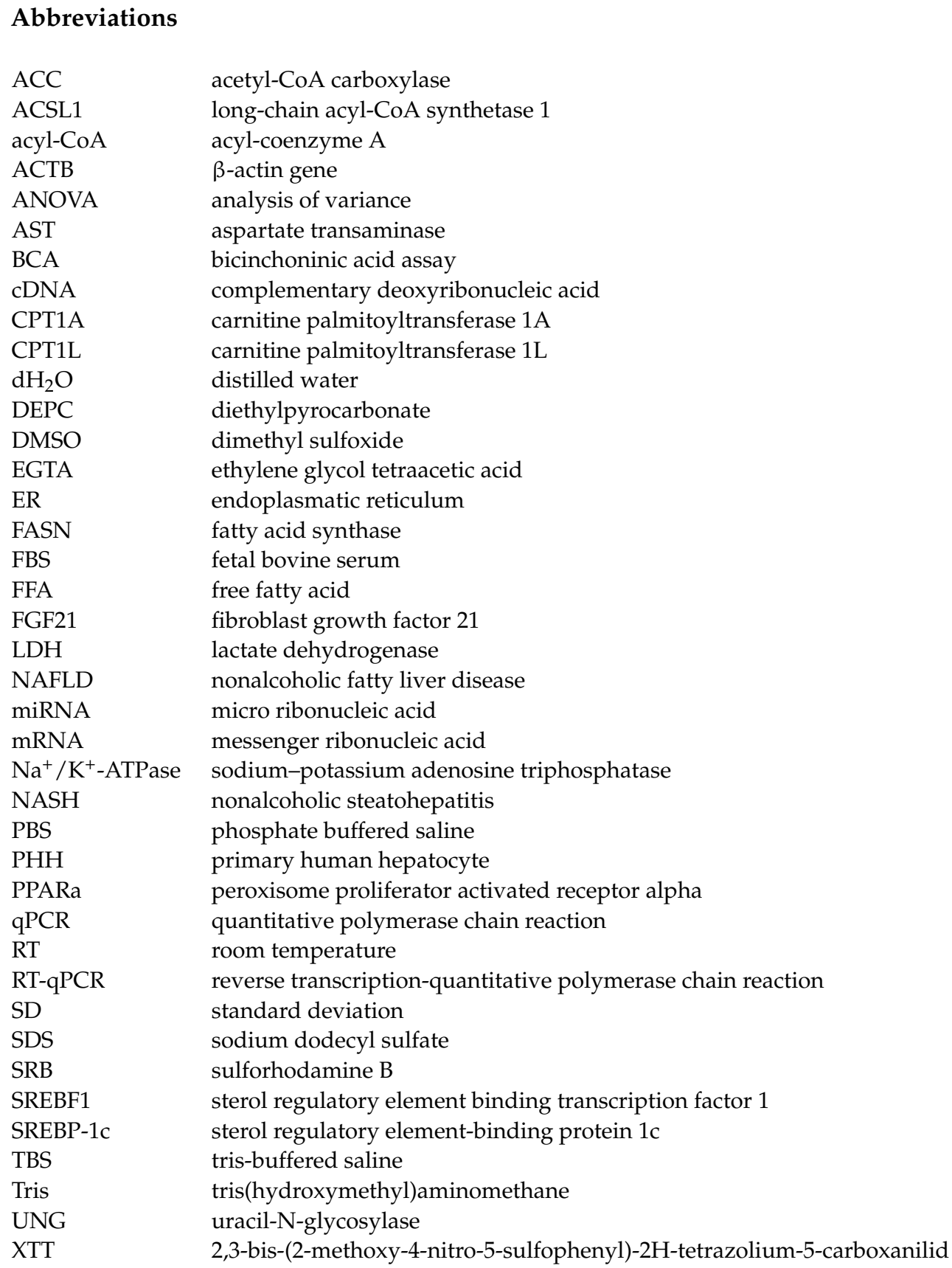




\section{References}

1. Younossi, Z.; Tacke, F.; Arrese, M.; Chander Sharma, B.; Mostafa, I.; Bugianesi, E.; Wai-Sun Wong, V.; Yilmaz, Y.; George, J.; Fan, J.; et al. Global Perspectives on Nonalcoholic Fatty Liver Disease and Nonalcoholic Steatohepatitis. Hepatology 2019, 69, $2672-2682$. [CrossRef]

2. Younossi, Z.M.; Koenig, A.B.; Abdelatif, D.; Fazel, Y.; Henry, L.; Wymer, M. Global epidemiology of nonalcoholic fatty liver disease-Meta-analytic assessment of prevalence, incidence, and outcomes. Hepatology 2016, 64, 73-84. [CrossRef] [PubMed]

3. Marchesini, G.; Bugianesi, E.; Forlani, G.; Cerrelli, F.; Lenzi, M.; Manini, R.; Natale, S.; Vanni, E.; Villanova, N.; Melchionda, N.; et al. Nonalcoholic fatty liver, steatohepatitis, and the metabolic syndrome. Hepatology 2003, 37, 917-923. [CrossRef]

4. Wong, R.J.; Aguilar, M.; Cheung, R.; Perumpail, R.B.; Harrison, S.A.; Younossi, Z.M.; Ahmed, A. Nonalcoholic steatohepatitis is the second leading etiology of liver disease among adults awaiting liver transplantation in the United States. Gastroenterology 2015, 148, 547-555. [CrossRef] [PubMed]

5. Pais, R.; Barritt, A.S.; Calmus, Y.; Scatton, O.; Runge, T.; Lebray, P.; Poynard, T.; Ratziu, V.; Conti, F. NAFLD and liver transplantation: Current burden and expected challenges. J. Hepatol. 2016, 65. [CrossRef]

6. Heimbach, J. Debate: A bridge too far-liver transplantation for nonalcoholic steatohepatitis will overwhelm the organ supply. Liver Transpl. 2014, 20 (Suppl. S2), S32-S37. [CrossRef] [PubMed]

7. Wallstab, C.; Eleftheriadou, D.; Schulz, T.; Damm, G.; Seehofer, D.; Borlak, J.; Holzhütter, H.-G.; Berndt, N. A unifying mathematical model of lipid droplet metabolism reveals key molecular players in the development of hepatic steatosis. FEBS J. 2017, 284, 3245-3261. [CrossRef] [PubMed]

8. Sanders, F.W.B.; Acharjee, A.; Walker, C.; Marney, L.; Roberts, L.D.; Imamura, F.; Jenkins, B.; Case, J.; Ray, S.; Virtue, S.; et al. Hepatic steatosis risk is partly driven by increased de novo lipogenesis following carbohydrate consumption. Genome Biol. 2018, 19, 79. [CrossRef]

9. Ipsen, D.H.; Lykkesfeldt, J.; Tveden-Nyborg, P. Molecular mechanisms of hepatic lipid accumulation in non-alcoholic fatty liver disease. Cell. Mol. Life Sci. 2018, 75, 3313-3327. [CrossRef]

10. Boeckmans, J.; Natale, A.; Buyl, K.; Rogiers, V.; de Kock, J.; Vanhaecke, T.; Rodrigues, R.M. Human-based systems: Mechanistic NASH modelling just around the corner? Pharmacol. Res. 2018, 134, 257-267. [CrossRef]

11. Varga, T.; Czimmerer, Z.; Nagy, L. PPARs are a unique set of fatty acid regulated transcription factors controlling both lipid metabolism and inflammation. Biochim. Biophys. Acta 2011, 1812, 1007-1022. [CrossRef]

12. Pawlak, M.; Lefebvre, P.; Staels, B. Molecular mechanism of PPAR $\alpha$ action and its impact on lipid metabolism, inflammation and fibrosis in non-alcoholic fatty liver disease. J. Hepatol. 2015, 62, 720-733. [CrossRef] [PubMed]

13. Yan, S.; Yang, X.-F.; Liu, H.-L.; Fu, N.; Ouyang, Y.; Qing, K. Long-chain acyl-CoA synthetase in fatty acid metabolism involved in liver and other diseases: An update. World J. Gastroenterol. 2015, 21, 3492-3498. [CrossRef]

14. Rakhshandehroo, M.; Hooiveld, G.; Müller, M.; Kersten, S. Comparative analysis of gene regulation by the transcription factor PPARalpha between mouse and human. PLoS ONE 2009, 4, e6796. [CrossRef] [PubMed]

15. Mashek, D.G. Hepatic fatty acid trafficking: Multiple forks in the road. Adv. Nutr. 2013, 4, 697-710. [CrossRef] [PubMed]

16. Hegarty, B.D.; Bobard, A.; Hainault, I.; Ferré, P.; Bossard, P.; Foufelle, F. Distinct roles of insulin and liver X receptor in the induction and cleavage of sterol regulatory element-binding protein-1c. Proc. Natl. Acad. Sci. USA 2005, 102, 791-796. [CrossRef]

17. Shimano, H.; Yahagi, N.; Amemiya-Kudo, M.; Hasty, A.H.; Osuga, J.; Tamura, Y.; Shionoiri, F.; Iizuka, Y.; Ohashi, K.; Harada, K.; et al. Sterol regulatory element-binding protein-1 as a key transcription factor for nutritional induction of lipogenic enzyme genes. J. Biol. Chem. 1999, 274, 35832-35839. [CrossRef] [PubMed]

18. Higuchi, N.; Kato, M.; Shundo, Y.; Tajiri, H.; Tanaka, M.; Yamashita, N.; Kohjima, M.; Kotoh, K.; Nakamuta, M.; Takayanagi, R.; et al. Liver $\mathrm{X}$ receptor in cooperation with SREBP-1c is a major lipid synthesis regulator in nonalcoholic fatty liver disease. Hepatol. Res. 2008, 38, 1122-1129. [CrossRef] [PubMed]

19. Kohjima, M.; Enjoji, M.; Higuchi, N.; Kato, M.; Kotoh, K.; Yoshimoto, T.; Fujino, T.; Yada, M.; Yada, R.; Harada, N.; et al. Re-evaluation of fatty acid metabolism-related gene expression in nonalcoholic fatty liver disease. Int. J. Mol. Med. 2007, 20, 351-358. [CrossRef]

20. Yanagitani, A.; Yamada, S.; Yasui, S.; Shimomura, T.; Murai, R.; Murawaki, Y.; Hashiguchi, K.; Kanbe, T.; Saeki, T.; Ichiba, M.; et al. Retinoic acid receptor alpha dominant negative form causes steatohepatitis and liver tumors in transgenic mice. Hepatology 2004, 40, 366-375. [CrossRef]

21. Seki, S.; Kitada, T.; Yamada, T.; Sakaguchi, H.; Nakatani, K.; Wakasa, K. In situ detection of lipid peroxidation and oxidative DNA damage in non-alcoholic fatty liver diseases. J. Hepatol. 2002, 37, 56-62. [CrossRef]

22. Stienstra, R.; Mandard, S.; Patsouris, D.; Maass, C.; Kersten, S.; Müller, M. Peroxisome proliferator-activated receptor alpha protects against obesity-induced hepatic inflammation. Endocrinology 2007, 148, 2753-2763. [CrossRef] [PubMed]

23. Gervois, P.; Kleemann, R.; Pilon, A.; Percevault, F.; Koenig, W.; Staels, B.; Kooistra, T. Global suppression of IL-6-induced acute phase response gene expression after chronic in vivo treatment with the peroxisome proliferator-activated receptor-alpha activator fenofibrate. J. Biol. Chem. 2004, 279, 16154-16160. [CrossRef] [PubMed]

24. Tomic, D.; Kemp, W.W.; Roberts, S.K. Nonalcoholic fatty liver disease: Current concepts, epidemiology and management strategies. Eur. J. Gastroenterol. Hepatol. 2018, 30, 1103-1115. [CrossRef] [PubMed]

25. Messina, M. Soy foods, isoflavones, and the health of postmenopausal women. Am. J. Clin. Nutr. 2014, 100 (Suppl. S1), 423S-430S. [CrossRef] 
26. Merritt, J.C. Metabolic syndrome: Soybean foods and serum lipids. J. Natl. Med. Assoc. 2004, 96, $1032-1041$.

27. Akhlaghi, M. Non-alcoholic Fatty Liver Disease: Beneficial Effects of Flavonoids. Phytother. Res. 2016, 30, 1559-1571. [CrossRef]

28. Amanat, S.; Eftekhari, M.H.; Fararouei, M.; Bagheri Lankarani, K.; Massoumi, S.J. Genistein supplementation improves insulin resistance and inflammatory state in non-alcoholic fatty liver patients: A randomized, controlled trial. Clin. Nutr. 2018, 37, 1210-1215. [CrossRef]

29. Zhong, H.; Liu, H.; Jiang, Z. Genistein Ameliorates Fat Accumulation through AMPK Activation in Fatty Acid-Induced BRL Cells. J. Food Sci. 2017, 82, 2719-2725. [CrossRef]

30. Yalniz, M.; Bahcecioglu, I.H.; Kuzu, N.; Poyrazoglu, O.K.; Bulmus, O.; Celebi, S.; Ustundag, B.; Ozercan, I.H.; Sahin, K. Preventive role of genistein in an experimental non-alcoholic steatohepatitis model. J. Gastroenterol. Hepatol. 2007, 22, 2009-2014. [CrossRef]

31. Huang, C.; Qiao, X.; Dong, B. Neonatal exposure to genistein ameliorates high-fat diet-induced non-alcoholic steatohepatitis in rats. Br. J. Nutr. 2011, 106, 105-113. [CrossRef] [PubMed]

32. Farruggio, S.; Cocomazzi, G.; Marotta, P.; Romito, R.; Surico, D.; Calamita, G.; Bellan, M.; Pirisi, M.; Grossini, E. Genistein and $17 \beta$-Estradiol Protect Hepatocytes from Fatty Degeneration by Mechanisms Involving Mitochondria, Inflammasome and Kinases Activation. Cell. Physiol. Biochem. 2020, 54, 401-416. [CrossRef] [PubMed]

33. Umemoto, T.; Fujiki, Y. Ligand-dependent nucleo-cytoplasmic shuttling of peroxisome proliferator-activated receptors, PPAR $\alpha$ and PPAR $\gamma$. Genes Cells 2012, 17, 576-596. [CrossRef] [PubMed]

34. Inoue, J.; Sato, R. New insights into the activation of sterol regulatory element-binding proteins by proteolytic processing. Biomol. Concepts 2013, 4, 417-423. [CrossRef] [PubMed]

35. Patel, R.P.; Barnes, S. Isoflavones and PPAR Signaling: A Critical Target in Cardiovascular, Metastatic, and Metabolic Disease. PPAR Res. 2010, 2010, 153252. [CrossRef]

36. Dufour, J.-F.; Caussy, C.; Loomba, R. Combination therapy for non-alcoholic steatohepatitis: Rationale, opportunities and challenges. Gut 2020, 69, 1877-1884. [CrossRef] [PubMed]

37. Buzzetti, E.; Pinzani, M.; Tsochatzis, E.A. The multiple-hit pathogenesis of non-alcoholic fatty liver disease (NAFLD). Metabolism 2016, 65, 1038-1048. [CrossRef]

38. Hedrington, M.S.; Davis, S.N. Peroxisome proliferator-activated receptor alpha-mediated drug toxicity in the liver. Expert Opin. Drug Metab. Toxicol. 2018, 14, 671-677. [CrossRef]

39. Zhang, S.; Kumari, S.; Gu, Y.; Wu, X.; Li, X.; Meng, G.; Zhang, Q.; Liu, L.; Wu, H.; Wang, Y.; et al. Soy Food Intake Is Inversely Associated with Newly Diagnosed Nonalcoholic Fatty Liver Disease in the TCLSIH Cohort Study. J. Nutr. 2020. [CrossRef]

40. Gómez-Lechón, M.J.; Donato, M.T.; Martínez-Romero, A.; Jiménez, N.; Castell, J.V.; O’Connor, J.-E. A human hepatocellular in vitro model to investigate steatosis. Chem. Biol. Interact. 2007, 165, 106-116. [CrossRef]

41. Rennert, C.; Heil, T.; Schicht, G.; Stilkerich, A.; Seidemann, L.; Kegel-Hübner, V.; Seehofer, D.; Damm, G. Prolonged Lipid Accumulation in Cultured Primary Human Hepatocytes Rather Leads to ER Stress than Oxidative Stress. Int. J. Mol. Sci. 2020, 21, 7097. [CrossRef]

42. Borlak, J.; Chougule, A.; Singh, P.K. How useful are clinical liver function tests in in vitro human hepatotoxicity assays? Toxicol. In Vitro 2014, 28, 784-795. [CrossRef] [PubMed]

43. Kliewer, S.A.; Sundseth, S.S.; Jones, S.A.; Brown, P.J.; Wisely, G.B.; Koble, C.S.; Devchand, P.; Wahli, W.; Willson, T.M.; Lenhard, J.M.; et al. Fatty acids and eicosanoids regulate gene expression through direct interactions with peroxisome proliferator-activated receptors alpha and gamma. Proc. Natl. Acad. Sci. USA 1997, 94, 4318-4323. [CrossRef] [PubMed]

44. Stellavato, A.; Pirozzi, A.V.A.; de Novellis, F.; Scognamiglio, I.; Vassallo, V.; Giori, A.M.; de Rosa, M.; Schiraldi, C. In vitro assessment of nutraceutical compounds and novel nutraceutical formulations in a liver-steatosis-based model. Lipids Health Dis. 2018, 17, 24. [CrossRef]

45. Rogue, A.; Anthérieu, S.; Vluggens, A.; Umbdenstock, T.; Claude, N.; de La Moureyre-Spire, C.; Weaver, R.J.; Guillouzo, A. PPAR agonists reduce steatosis in oleic acid-overloaded HepaRG cells. Toxicol. Appl. Pharmacol. 2014, 276, 73-81. [CrossRef]

46. Jump, D.B. Dietary polyunsaturated fatty acids and regulation of gene transcription. Curr. Opin. Lipidol. 2002, 13, 155-164. [CrossRef]

47. Gori, M.; Barbaro, B.; Arciello, M.; Maggio, R.; Viscomi, C.; Longo, A.; Balsano, C. Protective effect of the Y220C mutant p53 against steatosis: Good news? J. Cell. Physiol. 2014, 229, 1182-1192. [CrossRef] [PubMed]

48. Kersten, S.; Stienstra, R. The role and regulation of the peroxisome proliferator activated receptor alpha in human liver. Biochimie 2017, 136, 75-84. [CrossRef] [PubMed]

49. Ferré, P.; Foufelle, F. Hepatic steatosis: A role for de novo lipogenesis and the transcription factor SREBP-1c. Diabetes Obes. Metab. 2010, 12 (Suppl. S2), 83-92. [CrossRef]

50. Einer, C.; Hohenester, S.; Wimmer, R.; Wottke, L.; Artmann, R.; Schulz, S.; Gosmann, C.; Simmons, A.; Leitzinger, C.; Eberhagen, C.; et al. Mitochondrial adaptation in steatotic mice. Mitochondrion 2018, 40, 1-12. [CrossRef]

51. Lee, J.; Park, J.-S.; Roh, Y.S. Molecular insights into the role of mitochondria in non-alcoholic fatty liver disease. Arch. Pharm. Res. 2019, 42, 935-946. [CrossRef] [PubMed]

52. Pool-Zobel, B.L.; Adlercreutz, H.; Glei, M.; Liegibel, U.M.; Sittlingon, J.; Rowland, I.; Wähälä, K.; Rechkemmer, G. Isoflavonoids and lignans have different potentials to modulate oxidative genetic damage in human colon cells. Carcinogenesis 2000, 21, 1247-1252. [CrossRef] [PubMed] 
53. Kim, S.; Shin, H.-J.; Kim, S.Y.; Kim, J.H.; Lee, Y.S.; Kim, D.-H.; Lee, M.-O. Genistein enhances expression of genes involved in fatty acid catabolism through activation of PPARalpha. Mol. Cell. Endocrinol. 2004, 220, 51-58. [CrossRef] [PubMed]

54. Lepri, S.R.; Sartori, D.; Semprebon, S.C.; Baranoski, A.; Coatti, G.C.; Mantovani, M.S. Genistein Affects Expression of Cytochrome P450 (CYP450) Genes in Hepatocellular Carcinoma (HEPG2/C3A) Cell Line. Drug Metab. Lett. 2018, 12, 138-144. [CrossRef]

55. Lu, R.; Zheng, Z.; Yin, Y.; Jiang, Z. Effect of Genistein on Cholesterol Metabolism-Related Genes in HepG2 Cell. J. Food Sci. 2019, 84, 2330-2336. [CrossRef]

56. Xin, X.; Chen, C.; Hu, Y.-Y.; Feng, Q. Protective effect of genistein on nonalcoholic fatty liver disease (NAFLD). Biomed. Pharmacother. 2019, 117, 109047. [CrossRef] [PubMed]

57. Lee, Y.M.; Choi, J.S.; Kim, M.H.; Jung, M.H.; Lee, Y.S.; Song, J. Effects of dietary genistein on hepatic lipid metabolism and mitochondrial function in mice fed high-fat diets. Nutrition 2006, 22, 956-964. [CrossRef] [PubMed]

58. Asrih, M.; Montessuit, C.; Philippe, J.; Jornayvaz, F.R. Free Fatty Acids Impair FGF21 Action in HepG2 Cells. Cell. Physiol. Biochem. 2015, 37, 1767-1778. [CrossRef]

59. Bougarne, N.; Weyers, B.; Desmet, S.J.; Deckers, J.; Ray, D.W.; Staels, B.; de Bosscher, K. Molecular Actions of PPAR $\alpha$ in Lipid Metabolism and Inflammation. Endocr. Rev. 2018, 39, 760-802. [CrossRef] [PubMed]

60. Zheng, L.; Lv, G.-c.; Sheng, J.; Yang, Y.-d. Effect of miRNA-10b in regulating cellular steatosis level by targeting PPAR-alpha expression, a novel mechanism for the pathogenesis of NAFLD. J. Gastroenterol. Hepatol. 2010, 25, 156-163. [CrossRef] [PubMed]

61. Blanquart, C.; Barbier, O.; Fruchart, J.-C.; Staels, B.; Glineur, C. Peroxisome proliferator-activated receptor alpha (PPARalpha) turnover by the ubiquitin-proteasome system controls the ligand-induced expression level of its target genes. J. Biol. Chem. 2002, 277, 37254-37259. [CrossRef]

62. Liu, H.; Zhong, H.; Yin, Y.; Jiang, Z. Genistein has beneficial effects on hepatic steatosis in high fat-high sucrose diet-treated rats. Biomed. Pharmacother. 2017, 91, 964-969. [CrossRef] [PubMed]

63. Shin, E.S.; Lee, H.H.; Cho, S.Y.; Park, H.W.; Lee, S.J.; Lee, T.R. Genistein downregulates SREBP-1 regulated gene expression by inhibiting site-1 protease expression in HepG2 cells. J. Nutr. 2007, 137, 1127-1131. [CrossRef] [PubMed]

64. Lee, M.-R.; Park, K.I.; Ma, J.Y. Leonurus japonicus Houtt Attenuates Nonalcoholic Fatty Liver Disease in Free Fatty Acid-Induced HepG2 Cells and Mice Fed a High-Fat Diet. Nutrients 2017, 10, 20. [CrossRef]

65. Kegel, V.; Deharde, D.; Pfeiffer, E.; Zeilinger, K.; Seehofer, D.; Damm, G. Protocol for Isolation of Primary Human Hepatocytes and Corresponding Major Populations of Non-parenchymal Liver Cells. J. Vis. Exp. 2016, e53069. [CrossRef] [PubMed]

66. Pfeiffer, E.; Kegel, V.; Zeilinger, K.; Hengstler, J.G.; Nüssler, A.K.; Seehofer, D.; Damm, G. Featured Article: Isolation, characterization, and cultivation of human hepatocytes and non-parenchymal liver cells. Exp. Biol. Med. 2015, 240, 645-656. [CrossRef] [PubMed]

67. Rajan, N.; Habermehl, J.; Coté, M.-F.; Doillon, C.J.; Mantovani, D. Preparation of ready-to-use, storable and reconstituted type I collagen from rat tail tendon for tissue engineering applications. Nat. Protoc. 2006, 1, 2753-2758. [CrossRef] [PubMed] 